\title{
Predation by an introduced clam as the likely cause of substantial declines in zooplankton of San Francisco Bay
}

\author{
William J. Kimmerer ${ }^{1,2}$, Ellen Gartside ${ }^{2}$, James J. Orsi ${ }^{3}$ \\ ${ }^{1}$ BioSystems Analysis Inc., 3152 Paradise Drive, Tiburon, California 94920, USA \\ ${ }^{2}$ San Francisco State University, Romberg Tiburon Center, 3150 Paradise Drive, Tiburon, California 94920, USA \\ ${ }^{3}$ California Department of Fish and Game, 4001 N. Wilson Way, Stockton, California 95209, USA
}

\begin{abstract}
The clam Potamocorbula amurensis was introduced into the San Francisco Bay estuary (California, USA) in 1986 and became abundant in late 1987. Within a year, chlorophyll concentration and the abundance of adults of 3 common estuarine copepod species had declined by 53 to $91 \%$, providing an opportunity to examine mechanisms by which benthic grazing might control the abundance of pelagic populations. Declines in chlorophyll and abundance of the 3 species of copepod coincided approximately with the geographic range of the clam population. The decline in abundance of the copepod Eurytemora affinis was accompanied by a decrease in the ratio of nauplii to adults, but not in the ratio of eggs to females. Therefore, the decline in abundance may be due to elevated mortality of nauplii rather than food limitation of reproductive rate. We argue that direct predation by $P$. amurensis is the cause of the reduced survival of nauplii, and therefore of the depressed abundance of adults. Experimentally determined clearance rates of $P$. amurensis on $E$. affinis nauplii averaged $0.11 \mathrm{l} \mathrm{clam}^{-1}$ $\mathrm{d}^{-1}$. If that clearance rate applied in the field, the clams could remove $8.2 \%$ of the nauplii $\mathrm{d}^{-1}$. This removal rate is sufficient to explain the observed rate of population decline. $P$ amurensis appears to have become well established, and copepod populations of the bay so far have failed to rebound. Thus this invasion may have permanent effects. In a broader sense, predation on zooplankton by soft-bottom benthos may be an important, and heretofore overlooked, source of mortality in shallow waters. Selectivity occurring through differences in escape response and vertical position could make bivalve predation an important influence on biomass and species composition of inshore zooplankton.
\end{abstract}

KEY WORDS: Potamocorbula amurensis - Eurytemora affinis · Predation · San Francisco Bay · Copepod Bivalve

\section{INTRODUCTION}

Benthic grazing is believed to control phytoplankton biomass in some shallow waters (Cloern 1982, Officer et al. 1982, Nichols 1985, Alpine \& Cloern 1992). A large body of literature indicates that certain benthic organisms can graze substantially on phytoplankton and small zooplankton (Williams 1980, Buss \& Jackson 1981, Wright et al. 1982, Ertman \& Jumars 1988, Bingham \& Walters 1989, MacIsaac et al. 1991). Bivalves can influence benthic recruitment or reduce the abundance of certain zooplankton by consuming small, relatively slow-moving forms such as bivalve larvae (Williams 1980, Ertman \& Jumars 1988). Much of the work on predation by benthos on zooplankton has been through inference from reduced settling rates of meroplankton near filtering adults (Cowden et al. 1984, Sebens \& Koehl 1984, Hunt et al. 1987, Ertman \& Jumars 1988, Young \& Gotelli 1988, but see Young 1989).

Predation on copepods has been described for benthic species including brittle stars and cnidarians (Ferrari \& Dearborn 1989, Sullivan \& Banzon 1990, Sullivan et al. 1991), but not bivalves (Horsted et al. 1988). Since bivalves are an important component of shallow soft-bottom benthos (Nichols 1985), a significant predation rate by bivalves could be a key limitation to zooplankton abundance and species composition. Yet, opportunities for observing such effects in the field are rare because of the difficulty in separating effects of benthos from other sources of mortality. 
The clam Potamocorbula amurensis arrived in San Francisco Bay, California, USA, in 1986, probably in ship ballast water (Carlton et al. 1990, Nichols et al. 1990). $P$. amurensis is a small ( 5 to $30 \mathrm{~mm}$ ) clam with an epibenthic habitat and apparently euryhaline distribution: it has been found at freshwater and seawater salinities. Its type locality is the Amur River in eastern Siberia. Little is known of its distribution, abundance, or ecology in the source region (Carlton et al. 1990).

Potanocorbula amurensis spread very rapidly, becoming abundant throughout the northern reach of the bay by mid-summer 1987, a period of drought (Carlton et al. 1990). This spread apparently occurred at the expense of other salt-tolerant benthic species, which, under these drought conditions, would ordinarily have invaded the northern reach by $1987-88$ (Nichols et al. 1990). This invasion, potentially disastrous to the food web of the upper estuary, offered a unique opportunity to observe the effects of benthic filter feeding on the plankton of the estuary. Alpine \& Cloern (1992) have demonstrated the influence of this clam on the phytoplankton of the estuary, while Werner \& Hollibaugh (1993) have shown it to be capable of consuming bacteria, although at a lower rate than phytoplankton.

Concurrent with the spread of Potamocorbula amurensis came a decrease in chlorophyll of about 5-fold and elimination of the spring bloom in 1988 to 1990 (Alpine \& Cloern 1992). This period has included the longest drought since the 1930s, and the diminution of chlorophyll was much greater than seen in a shorter but more severe drought in 1976-77 (Arthur \& Ball 1979, Cloern et al. 1983, Alpine \& Cloern 1992). At the same time the abundance of several common estuarine copepod species declined markedly, leading to the belief that the clam was influencing copepod abundance either indirectly through reduction of food supply or directly through predation.

In this paper we describe circumstantial evidence supporting the theory that the rapid decline in copepod abundance was caused by predation by the clams on copepod nauplii, rather than through reduction in food supply. We focus on abundance patterns of the copepods Eurytemora affinis, Sinocalanus doerrii, and Acartia spp., which were historically the most abundant species in the upper estuary (Ambler et al. 1985, Orsi \& Mecum 1986). In particular, E. affinis was of interest because it occupies the salinity range 1 to 6 psu (Orsi \& Mecum 1986), where a large part of the monitoring effort has been concentrated and where the clam was known to be abundant (Alpine \& Cloern 1992). E. affinis is a widely distributed estuarine pelagic copepod with a broad range of salinity tolerance (ca 0 to 25 psu; Roddie et al. 1984, Nagaraj 1992). Unlike Acartia species, which are broadcast spawners, or $S$. doerrii, which releases eggs in clumps of up to 4 , $E$. affinis carries its eggs in a single egg sac. S. doerrii was introduced to the estuary around 1979 and has since been abundant at a position slightly upstream of the center of population of E. affinis (Orsi et al. 1983).

San Francisco Bay (Fig. 1) is one of the most urbanized estuaries, with one of the most closely managed freshwater flow regimes, in the world (Nichols et al. 1986). Most of the freshwater flow enters the estuary from the Sacramento and San Joaquin Rivers, which discharge through an extensive delta. We concentrate on the reach of the estuary including Suisun Bay and the western delta (Fig. 1), where Potamocorbula amurensis is abundant (Hymanson 1991). This reach includes broad shoal areas and several deep $(20 \mathrm{~m})$ channels. Tidal currents in this region can exceed $2 \mathrm{~m} \mathrm{~s}^{-1}$.

\section{MATERIALS AND METHODS}

Freshwater flow data were obtained from the California Department of Water Resources (DWR) Dayflow program. This program calculates a hypothetical net freshwater outflow through the western delta into the estuary at the nominal location of Chipps Island (river $\mathrm{km}$ 75, Fig. 1). Net delta outflow is the difference between inputs to the delta, consisting of gaged and ungaged river flows and precipitation less evaporation, and withdrawals, including consumption by farms within the delta and export flows at several major pumping facilities (Fig. 1). Monthly net delta outflow estimates were corrected using recently revised estimates of consumption in the delta from DWR (T. Kadir, DWR, pers. comm.).

Zooplankton data. Zooplankton abundance data were obtained from the California Department of Fish and Game zooplankton monitoring program, for which methods are described more fully in Orsi \& Mecum (1986). Samples were taken at ca 35 to 40 stations throughout the upper estuary (Fig. 1), monthly in March and November and twice monthly in April to October, 1972 to 1992. Samples were taken with a $154 \mu \mathrm{m}$ mesh, $10 \mathrm{~cm}$ diameter Clarke-Bumpus net towed obliquely from the bottom to the surface, and with a pump whose intake was slowly raised through the water column. The net sample and a $1.7 \mathrm{l} \mathrm{com-}$ posite subsample of the pump discharge were preserved in $5 \%$ formaldehyde.

In the laboratory the zooplankton net sample was concentrated on a $154 \mu \mathrm{m}$ mesh screen and subsampled to obtain at least 200 animals for counting. The pump sample was passed through a $154 \mu \mathrm{m}$ mesh screen and collected on a $43 \mu \mathrm{m}$ mesh screen, and the entire sample was counted. Adult copepods were iden- 


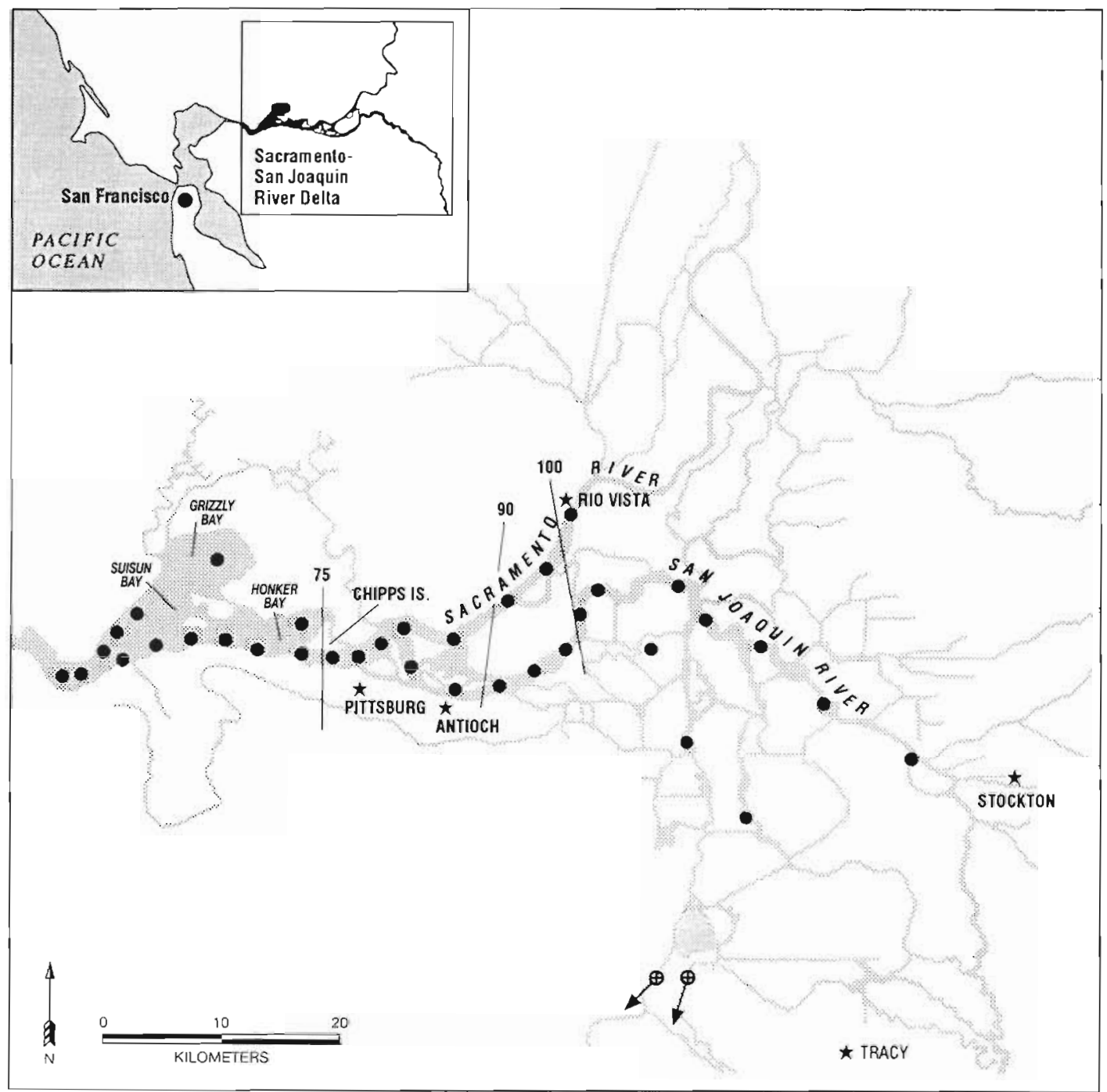

Fig. 1. Upper San Francisco Bay estuary, showing location of stations used in sampling and river kulometers mentıoned in the text. Arrows at the bottom of the figure indicate the sites of the 2 major export pumping faclities

tified to species or genus. Naupliı were identified to species for Eurytemora affinis only for 1985 to 1989 Abundance was calculated as the sum of abundance values from the net and pump samples after fractionation. Ratios of nauplii to adults were calculated for 1985 to 1989 ; if the egg production and egg mortalnty rates are constant this ratio is inversely related to the mortality rate of nauplii (Kimmerer 1987).

Egg ratios of Eurytemora affinis were determined using 62 samples from spring (March to May) 1984 to 1990. Samples from other seasons were not chosen because there were usually too few $E$. affinis in summer and fall after 1987. Females and eggs in entire samples were counted if available; in some cases only subsamples had been archived. Eggs were identified as either attached, in detached egg sacs, or as loose eggs. The latter could not be unequivocally identıfied to species, and were most abundant when Acartia spp. were abundant, so only eggs in egg sacs were included in the counts. Females were counted whether or not they had eggs, so that the mean population egg ratio was being estimated Egg ratios are proportional to egg production rate at a constant egg development time, which depends on temperature (McLaren 1965, Edmondson 1968); temperature had no systematic variation before versus after 1987 . At a constant temperature, egg ratios and egg production rate can be limited by food supply, either because of reduced number of eggs per clutch or an increased interval between clutches.

A vertıcally stratified series of $0.5 \mathrm{~m}^{3}$ pump samples was taken on July 21 to 22,1986 at about 1.2 psu salınity, near the maximum in abundance of Eurytemora affinis. Samples were taken hourly at $1 \mathrm{~m}$, mid- 
depth, and $1 \mathrm{~m}$ off the bottom, and all $E$. affinis were identified to life stage and counted. For the present purposes, the abundance of nauplii at each depth was used to determine their relative abundance in the near-bottom samples, and thereby their relative vulnerability to benthic predation.

At each station surface specific conductance and temperature were measured with a conductivity meter, and samples were taken for chlorophyll a analysis beginning in 1976. Salinity was determined from specific conductance according to the Practical Salinity Scale (UNESCO 1981) and is thus given in practical salinity units (psu). Additional salinity data were obtained from daily means of surface specific conductance from a continuous monitoring station at river km 75 (DWR station near Chipps Island, Fig. 1).

Data analysis. Chlorophyll a concentrations and abundance of copepods are closely related to salinity, with peaks at intermediate salinities and lower values at higher and lower salinities (see Fig. 2). The salt field moves considerably with changes in freshwater flow (Peterson et $\mathrm{a}_{\text {. }}$ 1975), so that the abundance peaks move as well. Temporal variation in abundance can therefore be confounded with variation due to movement of the salt field; similarly, seasonal effects can obscure longer-term trends. Since we were interested in temporal patterns other than those due to season and to movement of the salt field, we eliminated these effects from the data as follows. Data from 1972 to 1987 were partitioned into 20 salinity classes, each having about 500 observations (Table 1). These salinity classes have mean salinities at roughly equal logarithmic intervals. First we plotted the mean chlorophyll $a$ and log abundance (with 10 added to allow for zero values) of each copepod species in each salinity class before and after the end of 1987 to determine at what salinities the declines occurred.

The next step was to determine the geographic range and therefore the salinity range likely to be affected by the clam. In 1991 the abundance of Potamocorbula amurensis was over $1000 \mathrm{~m}^{-2}$ up to about river $\mathrm{km} 75$. and between 1 and $1000 \mathrm{~m}^{-2}$ to about $\mathrm{km} 90$ (Hymanson 1991). The tidal excursion is about $10 \mathrm{~km}$ in this region; thus the effect of the clam population should be detectable up to a nominal position of river $\mathrm{km} 100$. This corresponds on average to a surface salinity of about 0.45 psu (Fig. 3), or salinity class 10 (Table 1 ).

Abundance anomalies were then calculated using all the data in salinity classes $\geq 10$ ( $\geq 16$ for Acartia species because they are not abundant at lower salinities). The mean of each combination of salinity class and month was subtracted from the raw data to obtain anomalies virtually independent of salinity and persistent seasonal variation. These anomalies were then combined into monthly means for determining the timing of step changes in abundance using time series analysis. Missing data, particularly for the months of December to February, were filled in using linear interpolation to satisfy the requirements of the data for time series analysis. We then applied intervention analysis to determine the magnitude and timing of the largest step changes in the data. Intervention analysis is useful in detecting step changes in data with significant autocorrelation (Shumway 1988).
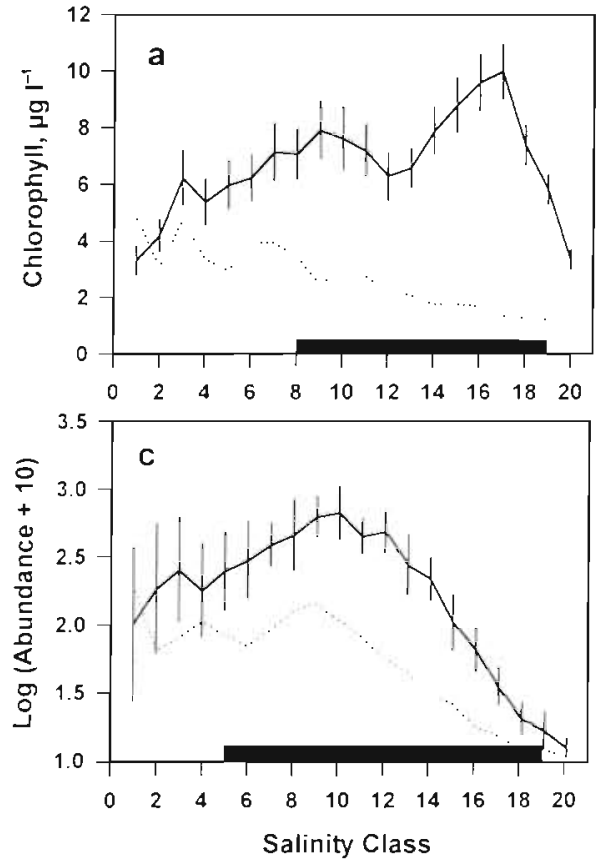
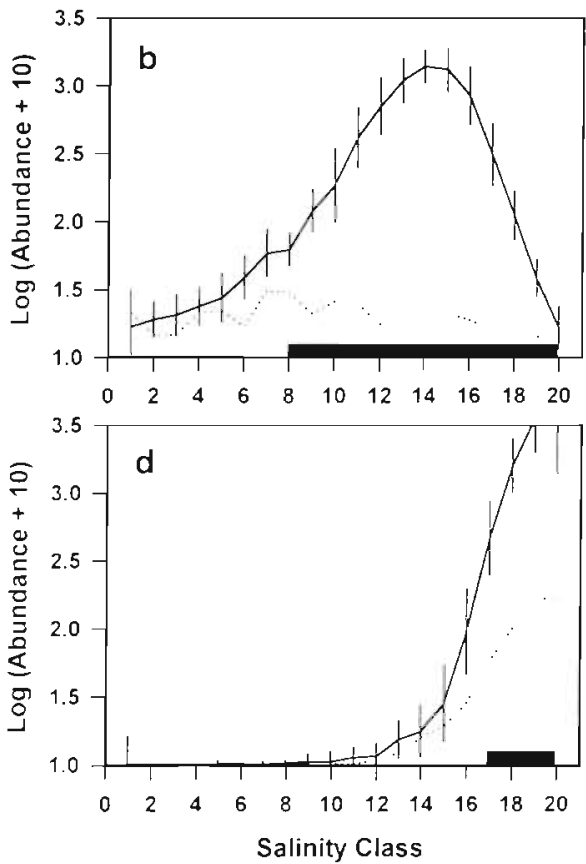

Fig. 2. San Franciso Bay estuary. Chlorophyll and $\log$ abundance (number $\mathrm{m}^{-3}+10$ ) of adults of common copepod species in 20 salinity classes during 1972 to 1987 (solid line with $95 \%$ confidence limits of the mean; series began in 1976 for chlorophyll, 1979 for Sinocalanus doerrii) and 1988 to 1992 (dotted line) Dark bars along the $x$-axis indicate salinity classes in which differences were significant $(t$ test on annual means, $\mathrm{p}<0.05$ ). (a) Chlorophyll; (b) Eurytemora affinis; (c) Sinocalanus doerrii (d) Acartia spp. 


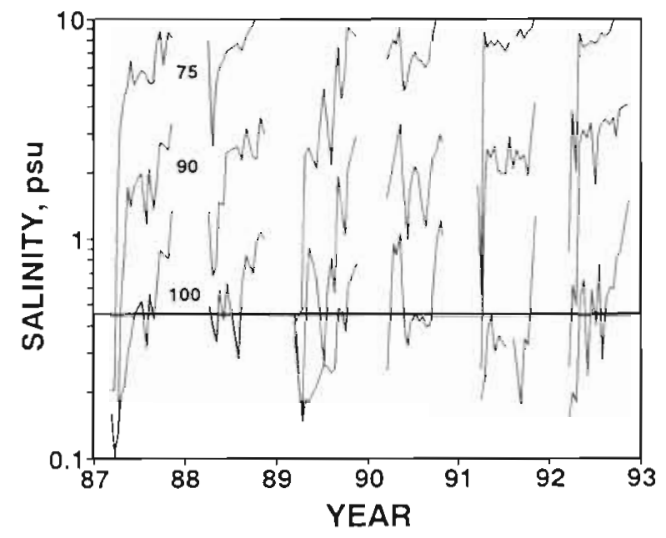

Fig. 3. San Franciso Bày estuary. Surface salinity from the

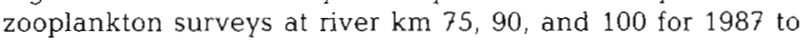
1992. The horizontal line is the geometric mean salinity at $100 \mathrm{~km}$ averaged from mid-1987 to the end of 1992

Experimental work. Experiments were conducted to determine whether clams could consume copepod nauplii, and some aspects of the mechanisms of capture. Clams for experiments were gathered from shallow locations in the upper estuary and maintained in aquaria with slowly flowing whole surface water for a few days before experiments. Copepod nauplii were collected by concentrating surface water from about 5 psu salinity through a $35 \mu \mathrm{m}$ mesh screen using upward flow to minimize damage. On one occasion nauplii from about 30 psu were used, and clams were gradually acclimated to the higher salinity. Nauplii were maintained for a few hours before experiments in insulated buckets of unscreened surface water at the experimental salinity and temperature.

We observed ingestion of copepod nauplii by Potamocorbula amurensis in petri dishes under a dissecting microscope. Nauplii of Eurytemora affinis, Acartia spp., Oithona spp., and Euterpina acutifrons were stained with neutral red to aid in observation and, in some of the observations, the clams were glued to the petri dishes. To detect escape responses, we conducted

Table 1. Salinity classes used in the analyses with upper limits of salinity (practical salinity units, psuj in each class

\begin{tabular}{|c|c|c|c|c|c|}
\hline $\begin{array}{l}\text { Salinity } \\
\text { class }\end{array}$ & $\begin{array}{l}\text { Upper } \\
\text { salinity }\end{array}$ & $\begin{array}{c}\text { Salinity } \\
\text { class }\end{array}$ & $\begin{array}{l}\text { Upper } \\
\text { salinity }\end{array}$ & $\begin{array}{c}\text { Salinity } \\
\text { class }\end{array}$ & $\begin{array}{l}\text { Upper } \\
\text { salinity }\end{array}$ \\
\hline 1 & 0.08 & 8 & 0.22 & 15 & 3.91 \\
\hline 2 & 0.09 & 9 & 0.31 & 16 & 5.32 \\
\hline 3 & 0.10 & 10 & 0.45 & 17 & 6.98 \\
\hline 4 & 0.11 & 11 & 0.69 & 18 & 8.95 \\
\hline 5 & 0.13 & 12 & 1.08 & 19 & 11.97 \\
\hline 6 & 0.14 & 13 & 1.79 & 20 & 20.17 \\
\hline 7 & 0.18 & 14 & 2.71 & & \\
\hline
\end{tabular}

a single series of artificial predation experiments (Singarajah 1969). A Pasteur pipet attached to a length of tubing was used to siphon $150 \mathrm{ml}$ of water out of $250 \mathrm{ml}$ of water containing $E$. affinis nauplii of mixed stages, in $2.25 \mathrm{~min}$. The mouth opening of the pipet was about $1 \mathrm{~mm}$, or about $10 \times$ the width of the larger nauplii. The nauplii in each fraction were counted and compared to the expected value, based on the proportion of water siphoned. Note that the flow velocity was considerably higher than expected in a clam siphon, so these results indicate only qualitatively the possibility that escape response explains differences in frequency of capture by clams.

A series of predation experiments was conducted to estimate the clearance rate of Potamocorbula amurensis on nauplii. Nauplii were divided among 8 insulated $40 \mathrm{l}$ tanks containing $30 \mathrm{l}$ of water from the same sampling site at temperatures slightly above ambient (20 to $25^{\circ} \mathrm{C}$ ). Mixing in the tanks was provided by a slowly (ca $1 \mathrm{rpm}$ ) rotating paddle. Clams were collected several days earlier and maintained in an aquarium with flowing whole surface water and an air stone. To begin the experiment 250 to 300 clams (mean shell length $8.5 \mathrm{~mm}$ ) were placed on plastic trays which were lowered into 4 of the tanks. The experiment was terminated by removing the clams, then draining and rinsing the tanks through a $35 \mu \mathrm{m}$ mesh screen and preserving the sample. Subsamples were taken with a stempel pipet, 200 to 500 nauplii were counted, and the number per liter in the tank was calculated from the fraction sampled and tank volume. Grazing rates were calculated as:

$$
g=\frac{V}{t C} \ln \left(\frac{N_{0}}{N}\right)
$$

where $g$ is the grazing rate $\left(\operatorname{llam}^{-1} \mathrm{~h}^{-1}\right), V$ is volume of the tank (l), $t$ is duration of the experiment in hours, $C$ is the number of clams, $N_{0}$ is the initial abundance, and $N$ the final abundance of nauplii in the tanks $\left(1^{-1}\right)$.

In a series of preliminary experiments, consumption rates of nauplii of several copepod species (Eurytemora affinis, Paracalanus quasimodo, Acartia spp., Oithona spp., and Euterpina acutifrons) were measured. Twelve clams were placed in each of four $1 \mathrm{l}$ beakers, and no clams in 4 controls. Nauplii obtained by rearing from field-caught females were added to each beaker in $700 \mathrm{ml}$ of water from the salinity range at which the copepods were collected. After $2 \mathrm{~h}$ incubation near ambient temperatures (around $20^{\circ} \mathrm{C}$ ), during which beakers were stirred manually every $10 \mathrm{~min}$ and clams were observed filtering, the contents of the beakers were strained through a $35 \mu \mathrm{m}$ mesh screen, stained with neutral red, preserved with formaldehyde, and counted. 
Table 2. Log chlorophyll and log abundance (number $\mathrm{m}^{-3}+$ 10) of 3 common copepods in the San Francisco Bay estuary before (1972 to 1987) and after (1989 to 1992) the clam Potamocorbula amurensis became abundant. Values are means and $95 \%$ confidence limits of annual mean values for salinity classes in which significant declines occurred (dark bars in Fig. 2), and percentage declines in the geometric means

\begin{tabular}{|lccc|}
\hline & Before 1988 & $1988-1992$ & $\begin{array}{c}\text { Percent } \\
\text { change }\end{array}$ \\
\hline Chlorophyll & $0.74 \pm 0.10$ & $0.23 \pm 0.18$ & $69 \%$ \\
Eurytemora affinis & $2.4 \pm 0.1$ & $1.3 \pm 0.2$ & $93 \%$ \\
Sinocalanus doerrij & $2.3 \pm 0.2$ & $1.6 \pm 0.2$ & $76 \%$ \\
Acartia spp. & $3.3 \pm 0.2$ & $2.1 \pm 0.2$ & $95 \%$ \\
\hline
\end{tabular}

\section{RESULTS}

\section{Changes in abundance}

Chlorophyll $a$ and the abundance of the 3 copepod species all declined substantially and significantly at higher salinities in their ranges (Fig. 2, Table 2). Except for Acartia spp., which is rare at low salinities, significant declines occurred in salinities down to about $0.17 \mathrm{psu}$.

The declines in copepod abundance were the most substantial changes in the data record from 1972
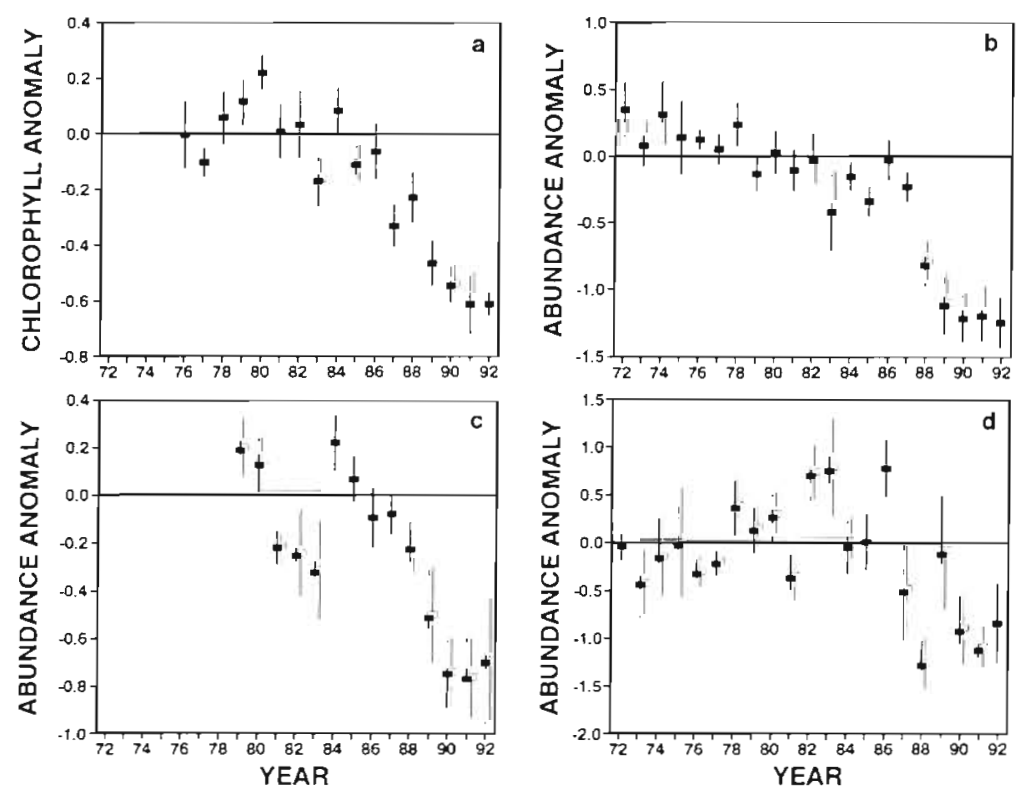

Fig. 4. San Franciso Bay estuary. Annual means and $95 \%$ confidence limits of anomalies in $\log$ chlorophyll concentration $\left(\mu \mathrm{g} \mathrm{l}^{-1}\right)$ and $\log$ abundance (number $\left.\mathrm{m}^{-3}+10\right)$ of common copepod species in salinity classes 10 to $20(16$ to 20 for Acartia spp.). (a) Chlorophyll; (b) Eurytemora affinis; (c) Sinocalanus doerrij; (d) Acartia spp.
Table 3. Results of intervention analysis on variables in the San Francisco Bay estuary to determine timing of change in anomalies of $\log$ chlorophyll and $\log$ abundance (number $\mathrm{m}^{-3}$ +10 ) of 3 common copepods for salinity classes 10 to 20 ( 16 to 20 for Acartia spp.). Values given are the $t$ value for testing the significance of the largest step change identified in the data, the date (month and year) at which that change occurred, and the percent change determined as (1 to 10 $0^{c}$, where $c$ is the coefficient of the step change

\begin{tabular}{|lrrc|}
\hline & $t$-value & Date & Percent change \\
\hline Chlorophyll & -6.0 & Jun 1987 & $-53 \%$ \\
Eurytemora affinis & -10.0 & Jan 1988 & $-88 \%$ \\
Sinocalanus doerrij & -7.0 & Sep 1988 & $-78 \%$ \\
Acartia spp. & -6.3 & Jul 1987 & $-91 \%$ \\
& & & \\
\hline
\end{tabular}

to 1992 . Intervention analysis showed several statistically significant step changes in each of the data series, the largest of which occurred during 1987-88 for chlorophyll $a$ and all 3 zooplankton species (Table 3). The decline in chlorophyll occurred in mid-1987, and the declines in copepod abundance followed in order Acartia spp., Eurytemora affinis, and Sinocalanus doerrii. These time periods are approximate since the declines occurred over a period of several months. Annual mean anomalies (Fig. 4) show considerable variability, but were lower after the dates determined by intervention analysis than before in every year except 1989 for Acartia spp. Some of the variability before the declines identified above can be explained by the effects of drought or flood (Alpine \& Cloern 1992).

The effect of grazing by clams may be confounded by the effects of variability in river flow (Alpine \& Cloern 1992). We plotted anomalies of chlorophyll a concentration and copepod abundance against the log of monthly mean net delta outflow for surveys before and after mid1987. Chlorophyll anomalies before mid1987 were generally higher at intermediate flows and lower at high and low flows (Fig. 5a). After mid-1987, chlorophyll was nearly uniformly low in spite of variation in outflow. The copepods had no apparent relationships with outflow (Fig. 5 b to d), except for some reduced values at high flows, probably due to inadequate sampling of the downstream region. The values after mid-1987 were generally low, particularly for Eurytemora affinis and Acartia spp. Seasonal patterns for both $E$. affinis and Acartia changed after 1987, with nearly normal values occurring dur- 
ing spring, when flows are high, and low values in the low-flow periods of summer and fall.

Log ratios of nauplii to adults of Eurytemora affinis were significantly lower in 1987 to 1989 than in 1985 and 1986. If the break is made after 1987 , the difference is still significant (Fig. 6; $p<0.0001$, nested ANOVA, Table 4). Egg ratios were variable among years, but not between groups of years, either 1984 to 1986 vs 1987 to 1990 or 1984 to 1987 vs 1988 to 1990 (Fig. 6; p $>0.1$, nested ANOVA, Table 4). The lowest annual mean egg ratio was in 1986, when nauplii and adults were moderately abundant, and there was no significant relationship between egg ratios and chlorophyll a (by inspection and linear regression, $r^{2}=0.04$ $34 \mathrm{df}, \mathrm{p}>0.1$ ).

Vertical distributions of Eurytemora affinis nauplii showed relatively little tendency of the nauplii to avoid deep water. The mean depth of the nauplii was $0.8 \pm 0.5$ m (mean with $95 \%$ confidence limits) above mid-depth, and the abundance at $1 \mathrm{~m}$ off the bottom averaged $77 \pm 13 \%$ (mean with $95 \%$ confidence limits) of the geometric mean for the water column. Thus, to a first approximation the nauplii are vulnerable to predation by the clams.

\section{Experimental results}

Eurytemora affinis nauplii had a moderately strong escape response to the shear caused by the incurrent flow of the clam siphons. This response often enabled them to evade the incurrent flow and sometimes to become entrained in the strong flow from the excurrent siphon. Nauplii that entered the incurrent siphon were not observed to emerge, and some were later found entangled in pseudofeces, apparently dead. We observed qualitative differences among copepod species in the ability to evade the siphon, with $E$. affinis and Acartia spp. having a moderate escape response, the harpacticoid Euterpina acutifrons having a strong response, and the neritic calanoid Paracalanus quasimodo having a weak or nonexistent response. Using a pipet as an artificial clam siphon, we found a significant escape response in the nauplii of $E$. affinis 135 of 263 nauplii captured by the siphon, $\chi^{2}=78$, $\mathrm{p}<0.0001,1 \mathrm{df}, 3$ experiments pooled).

Clams consumed Eurytemora affinis nauplii and chlorophyll a at significant rates in all 8 tank experiments (Fig. 7). Filtration rates averaged $0.0051 \mathrm{clam}^{-1}$

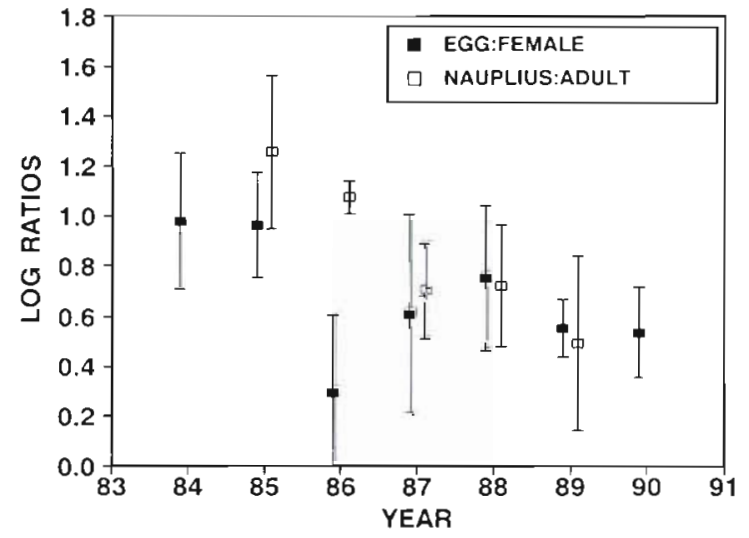

Fig. 6. Eurytemora affinis in the San Franciso Bay estuary. Ratios of nauplii to adults for salinity classes 10 to 19 , between 0.3 and 10 psu; and ratios of eggs to females for March to May in salinity classes 10 to 19 . Means and $95 \%$ confidence limits by year

$\mathrm{h}^{-1}$ on nauplii, and $0.038 \mathrm{l} \mathrm{clam}^{-1} \mathrm{~h}^{-1}$ for chlorophyll. The apparent downward trend in Fig. 7 for $E$. affinis may have been related to ambient temperature, which increased during this period, although experimental temperature did not show a trend (Fig. 7).

In a single preliminary experiment using beakers, filtration rates on Eurytemora affinis nauplii averaged $0.031 \mathrm{clam}^{-1} \mathrm{~h}^{-1}$. In preliminary experiments using nauplii from higher salinity (ca 30 psu), clearance rates were highest on Paracalanus quasimodo, lower on Acartia spp., and not significantly different from 0 on Euterpina acutifrons. 
Table 4. Analysis of variance results for ratios of nauplii to adults (top) and eggs to females (bottom). Results compare pre-clam with post-clam groups of years, with 1987 being assigned to the former (left) or the latter (right). Results indicated as either significant at $p<0.01(\cdots)$ or $p<0.001(\cdots)$ or not significant

\begin{tabular}{|c|c|c|c|c|c|c|c|c|}
\hline \multirow[t]{2}{*}{ Source } & \multicolumn{4}{|c|}{$1985-1987$ vs $1988-1989$} & \multicolumn{4}{|c|}{$1985-1986$ vs $1987-1989$} \\
\hline & $\begin{array}{l}\text { Sum of } \\
\text { squares }\end{array}$ & $\mathrm{df}$ & $\begin{array}{l}\text { Mean } \\
\text { square }\end{array}$ & $F$ & $\begin{array}{l}\text { Sum of } \\
\text { squares }\end{array}$ & df & $\begin{array}{l}\text { Mean } \\
\text { square }\end{array}$ & $F$ \\
\hline \multicolumn{9}{|c|}{ Nauplii to adult ratio } \\
\hline Year group & 1.49 & 1 & 1.49 & $16.09 \cdots$ & 2.61 & 1 & 2.61 & $28.3 \cdots$ \\
\hline Year within group & 1.64 & 3 & 0.55 & $5.91 \cdots$ & 0.37 & 3 & 0.12 & 1.32 \\
\hline Error & 3.24 & 35 & 0.09 & & 3.32 & 35 & 0.09 & \\
\hline \multirow[t]{2}{*}{ Source } & \multicolumn{4}{|c|}{$1984-1987$ vs $1988-1990$} & \multicolumn{4}{|c|}{$1984-1986$ vs $1987-1990$} \\
\hline & $\begin{array}{l}\text { Sum of } \\
\text { squares }\end{array}$ & $\mathrm{df}$ & $\begin{array}{l}\text { Mean } \\
\text { square }\end{array}$ & $F$ & $\begin{array}{c}\text { Sum of } \\
\text { squares }\end{array}$ & df & $\begin{array}{l}\text { Mean } \\
\text { square }\end{array}$ & $F$ \\
\hline \multicolumn{9}{|l|}{ Egg to female ratio } \\
\hline Year group & 0.14 & 1 & 0.14 & 1.41 & 0.27 & 1 & 0.27 & 2.66 \\
\hline Year within group & 3.06 & 5 & 0.61 & $6.02 \cdots$ & 2.90 & 5 & 0.58 & $5.72 \cdots$ \\
\hline Error & 5.69 & 56 & 0.10 & & 5.69 & 56 & 0.10 & \\
\hline
\end{tabular}

\section{DISCUSSION}

This may be the first demonstration of a major impact by bivalves on populations of estuarine copepods. This result was a fortuitous outcome of an ecological disaster, the introduction of a competent and prolific exotic species to San Francisco Bay. The finding that bivalves can have such an impact on copepod populations may have strong implications for all shallow estuaries with abundant bivalves. Therefore, we examine below the steps leading to the conclusion that predation by the clams caused the decline in copepods.

The evidence developed here is circumstantial in that direct measurements of in situ consumption rates were not made. To date, field consumption rates of phytoplankton by bivalves have been measured only a few times, usually under conditions of low flow velocities, shallow water, and high bivalve densities, such as over mussel beds (Wright et al. 1982, Frechétte \& Bourget 1985a, Muschenheim \& Newell 1992). To our knowledge, all studies reporting broad-scale effects on phytoplankton have been based on laboratory values of grazing rates rather than field measurements of grazing (e.g. Cloern 1982, Officer et al. 1982, Cohen et al. 1984, Loo \& Rosenberg 1989, Alpine \& Cloern 1992). The principal difficulties seem to be patchiness in grazing rates and logistical problems in working in deep water with strong tidal currents. The former difficulty would be magnified for zooplankton, since the consumption rates and densities of nauplii are lower than for phytoplankton. In addition, knowledge of population dynamics of the copepods would be required to place the mortality in context. Sufficiently detailed measurements of population dynamics of estuarine zooplankton have been made only once (Landry 1978) for a population in a small, enclosed body of water; doing a similar study on a population in a dynamic estuary would be extremely difficult. Thus, practical impediments prevent a thorough test of the theory that

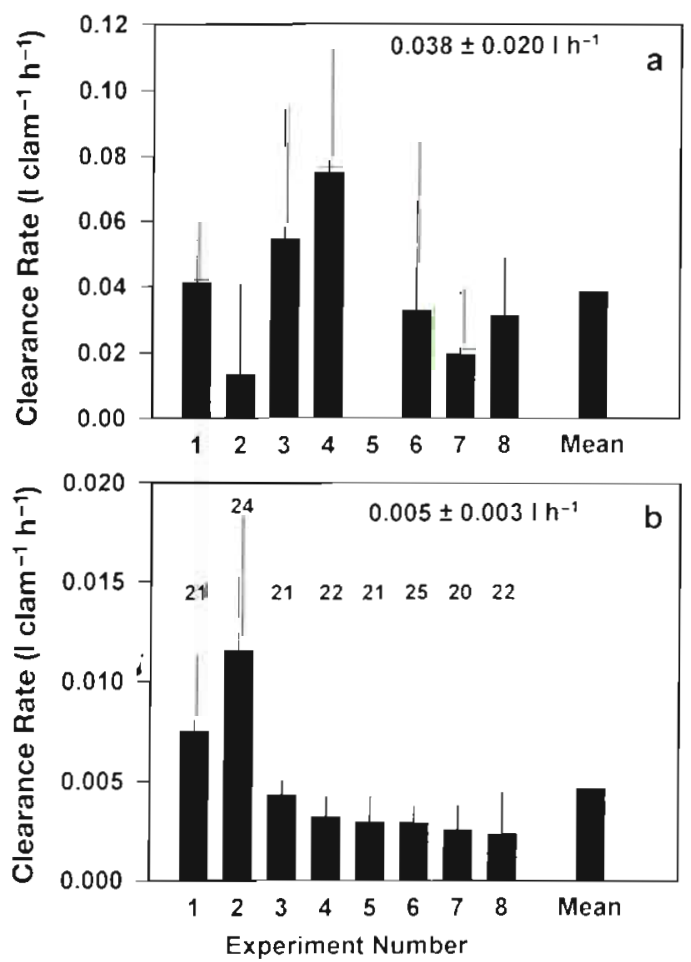

Fig. 7. San Franciso Bay estuary. Experimentally determined grazing rate (mean \pm range, $1 \mathrm{clam}^{-1} \mathrm{~h}^{-1}$ ) of the introduced clam Potamocorbula amurensis on (a) chlorophyll and (b) Eurytemora affinis nauplii. Numbers in (b) are temperatures $\left({ }^{\circ} \mathrm{C}\right)$ during experiments 
predation by clams exerts significant mortality on the copepod populations, and we are forced to rely on inference.

\section{Declines in abundance}

The decline in copepod abundance nearly concurrent with the spread of Potamocorbula amurensis is the first piece of evidence that the two are related. These declines are the largest and sharpest long-term decreases in abundance we are aware of for estuarine zooplankton species. The coincidence of the declines in copepod abundance with the increase in clam abundance can be seen by comparing Fig. 4 with Fig. 3 in Carlton et al. (1990) and Fig. 3 in Alpine \& Cloern (1992), which show the abundance of $P$. amurensis to have increased by summer 1987 to values often exceeding $1000 \mathrm{~m}^{-2}$ in Suisun and San Pablo Bays. On strictly statistical grounds it could be argued that this offers only 2 points (before and after), providing no power for testing the strength of the interaction. However, the declines in these copepod species were the largest on record, exceeding all previous declines, and no other potential cause has been identified. Furthermore, a 5- to 10 -fold decline in abundance of 3 species within a year would appear to rule out such causes as diseases and parasites, which would presumably be species-specific. Other potential predators such as small fish have, if anything, declined during the same period (Herbold et al. 1992).

Based on the intervention analysis, the decline in chlorophyll occurred nearly simultaneously with the outbreak of the clam population in summer 1987. The abundance of the 3 copepod species declined in order of the degree of exposure to predation, with Acartia spp. declining first followed by Eurytemora affinis and, later, Sinocalanus doerrii. Of these 3 copepod taxa, $S$. doerrii occupies the most freshwater habitat, with the bulk of the population at a salinity range below 1 psu or salinity class 12 , generally upstream of river $\mathrm{km} 90$ (Figs. $2 \& 3$ ). Thus the population of $S$. doerrii was upstream of the bulk of the Potamocorbula amurensis population for most of the period, resulting in reduced exposure. Considering the degree of exposure of these populations, the timing of declines of copepods coincides with the spread of the $P$. amurensis population.

The declines in copepod abundance were almost certainly not related to the drought. Freshwater flow since the invasion has been low but within the range of previously observed values, while copepod abundance values have been extraordinarily low. There was no apparent relationship between flow and copepod abundance before or after the clam invasion (Fig. 5).
Previous droughts have been characterized by invasions of other bivalves, notably Mya arenaria (Nichols 1985), that may have reduced phytoplankton biomass in 1977 (Alpine \& Cloern 1992). There are 3 possible explanations why no effect of that grazing was observed on zooplankton. First, chlorophyll concentration during that period was about an order of magnitude higher than in the more recent drought (Fig. 3 in Alpine \& Cloern 1992). If this implies an order of magnitude lower grazing rate, the resulting effect on zooplankton would not be detectable over the limited period of that drought. Second, salinity in the area affected by $M$. arenaria was too high for most of the copepod populations except Acartia spp. Third, $M$. arenaria is an infaunal species, in contrast to the epifaunal habitat of Potamocorbula amurenesis. The difference in habitat may imply differences in grazing effect on nauplii.

\section{Causal mechanisms}

If the decline in copepod populations was caused by Potamocorbula amurensis, there are 2 plausible mechanisms: (1) consumption of nauplii (and eggs, for copepods that release their eggs into the water) by $P$. amurensis, and (2) reduction in food availability due to grazing by the clams. Evidence for a decline in chlorophyll has already been presented (Alpine \& Cloern 1992), and is supported by the data in Figs. 2, $4 \& 5$, although Eurytemora affinis is also capable of feeding on detritus (Heinle \& Flemer 1975). We argue here that $E$. affinis was probably more affected by predation than competition, although we cannot make the same argument for the other copepod species.

Reduction in food could lower reproductive rates of the copepods, reduce development rates of nauplii, or increase their mortality rates. Only the mortality rates of the nauplii would be affected by direct predation on the nauplii. However, all of these would manifest themselves as reduced abundance of nauplii relative to adults, as was observed.

Growth rates of juvenile stages of copepods are generally believed to continue into the adult stages, at least for the female, where they are expressed as egg production (Sekiguchi et al. 1980, Berggreen et al. 1988). Reproductive rates appear to be at least as sensitive as growth rates of copepodites to reduction in food availability (Berggreen et al. 1988). Data on food limitation of nauplii are scarce. Feeding rates of Calanus pacificus nauplii and stage I copepodites saturate at similar food concentrations (Fernandez 1979), and the concentrations of food needed to saturate feeding rates increase with increasing copepodite stage (Vidal 1980). This suggests that in C pacificus at least, 
food limitation should occur in the reproductive rates of the adults before it shows up in the feeding rates of nauplii. If that is true of copepods in general, then one should seek evidence of food limitation in the egg production rate of the adults. There is some evidence from the field to suggest that early life stages of copepods are less food-limited than later, particularly adult, stages (Runge et al. 1985, Peterson et al. 1991, Walker \& Peterson 1991). To our knowledge there is no example of a copepod population in which nauplii or early copepodites were food-limited while adults were satiated.

The egg ratio of Eurytemora affinis was presented as a surrogate for egg production rate. Since temperature was not different among the years of the study, reproductive rates should be closely correlated with egg ratios. No decline in egg ratios was observed in 1987 , and the lowest annual value was seen in 1986, before the spread of Potamocorbula amurensis. Furthermore, egg ratios during this time were uncorrelated with chlorophyll (we do not know the reasons for the interannual variation, such as the low value in 1986). Therefore, egg production after 1987 was not more food limited than before, in spite of the reduction in phytoplankton that attended the spread of the clam. By the assumptions in the previous paragraph, the growth rates of the nauplii (and therefore their mortality rates in the absence of predation) would not have changed. This leaves predation as the likely cause of the reduced abundance of nauplii, although the possibility of food limitation could never be completely eliminated.

Acartia species apparently are food limited in south San Francisco Bay in spring (Kimmerer unpubl, data), so the possibility of competition for food is higher with this species. On the other hand, Acartia spp. release their eggs, which are negatively buoyant and would be vulnerable to consumption by clams. Thus either predation or competition could be the dominant influence on the abundance of Acartia.

The behavioral observations demonstrated that Potamocorbula amurensis is capable of ingesting copepod nauplii, and the experiments in tanks demonstrated significant consumption rates on Eurytemora affinis. This is not too surprising given the strength of the feeding currents observed. However, ingestion of copepod nauplii by bivalves has been only infrequently demonstrated before (Horsted et al. 1988).

The vertical distribution of nauplii in the water column suggests that they should be vulnerable to ingestion by the field population of clams unless there is a depletion of nauplii in the benthic boundary layer. Such a depletion has been observed for phytoplankton and bacteria over dense mussel beds (Fréchette \& Bourget 1985b, Fréchette et al. 1989, Muschenheim \&
Newell 1992). Recent experiments with beds of artificial clams scaled to represent Potamocorbula amurensis (11000 siphons $\mathrm{m}^{-2}$ ) have shown a maximum depletion in concentration of about $50 \%$ for a substance that is filtered with $100 \%$ efficiency (O'Riordan et al. in press; see also Monismith et al. 1990). The efficiency of pumping (i.e. effective filtration rate divided by pumping rate) for chlorophyll is probably much less than $100 \%$ (see Doering \& Oviatt 1986), so that for nauplii should be less than $13 \%$, based on the ratio of consumption of nauplii to chlorophyll in our experiments. Assuming a filtration efficiency of $13 \%$, and a mean density of 3500 clams $^{-2}$ (Hymanson 1991), the depletion of nauplii would amount to about $2 \%$ in the concentration boundary layer. Thus, clam grazing would not lead to a measurable depletion in concentration of nauplii in the benthic boundary layer. On the other hand, a behavioral avoidance of the bottom by the nauplii, not addressed in this study, could result in a reduced effect of consumption by clams.

\section{Field clearance rates}

Other workers on this species have obtained clearance rates on chlorophyll of 0.9 to $4.7 \mathrm{l} \mathrm{clam}^{-1} \mathrm{~d}^{-1}$ (Cole et al. 1992, Werner \& Hollibaugh 1993) higher than those we observed. Their rates could have been biased upward by their use of cultured rather than natural phytoplankton (Doering \& Oviatt 1986). If our experimental design resulted in low estimates of the clearance rates for chlorophyll, then our clearance rates for nauplii may also be underestimates.

Measurement of grazing rates of bivalves is complicated by their responses to a variety of factors including seston concentration, flow, and substrate type (Morton 1983, Fréchette \& Bourget 1985a, Eckman et al. 1989, Levinton 1991, Cole et al. 1992). Thus the observed clearance rates are unlikely to match closely the rates that would pertain in the field. A better method of estimating grazing rates is through the use of recirculating flumes (Cole et al. 1992), although scaling these properly can be difficult (Jumars \& Nowell 1984). In any event, it is unlikely that any experimental setup would suffice to determine field grazing rates. Since direct measurements of these rates is also extremely difficult given field conditions (see above), we are left with indirect demonstrations of the influence of predation by Potamocorbula amurensis.

In view of the problems extrapolating laboratory rates to the field, we must take these rates as only order-of-magnitude estimates of what the field rates could be. It is still instructive to calculate the predatory impact on the copepod population to determine whether predation could be responsible for the 
Table 5. Calculation of impact of Potamocorbula amurensis grazing on Eurytemora affinis nauplii. The principal assumption is that filtration rates in the experiments are the same as those in the fjeld

\begin{tabular}{|lcl|}
\hline & Value & Source \\
\hline Grazing rate $\left(\mathrm{l} \mathrm{clam}^{-1} \mathrm{~h}^{-1}\right)$ & 0.005 & From Fig. 7 \\
Mean weight of clams $(\mathrm{g})$ & 0.17 & Mean of all experiments \\
Corresponding shell length $(\mathrm{cm})$ & 1.1 & Hollibaugh \& Werner (1993) \\
Median shell length in field $(\mathrm{cm})$ & 0.85 & Hymanson (1991) \\
Factor to correct rate for size & 0.78 & Hollibaugh \& Werner (1993) \\
Field grazing rate $\left(1 \mathrm{clam} \mathrm{m}^{-1} \mathrm{~d}^{-1}\right)$ & 0.094 & Multiply grazing rate by correction factor and $24 \mathrm{~h} \mathrm{~d}^{-1}$ \\
Field abundance of clams $\left(\mathrm{m}^{-2}\right)$ & 3500 & Hymanson (1991), DWR monitoring data \\
Mean depth $(\mathrm{m})$ & 4 & Nautical charts, area between river km 55 and 75 \\
Grazing impact $\left(\mathrm{d}^{-1}\right)$ & 0.082 & Multiply grazing rate by abundance, divide by depth and by 1000 \\
Proportion of time as nauplius & 0.35 & Heinle \& Flemer (1975) \\
Effective mortality in population $\left(\mathrm{d}^{-1}\right)$ & 0.029 & Multiply grazing impact by relative duration \\
Days to reach $12 \%$ of population & 73 & From effective mortality, assuming that it is in excess over mortality \\
& & of steady-state population \\
\end{tabular}

observed decline. Calculations are summarized in Table 5. We calculated consumption rates in percent of the water column cleared per day from the measured filtration rates, the abundance of clams in the upper estuary, and the mean depth. We then converted this to a daily mortality rate of the nauplii and calculated the rate of decline of the population, assuming that the mortality is excess over that existing in the population before clams arrived, and that no compensatory response of the population occurred during this time period. We estimate that the clams were consuming on average $8.2 \% \mathrm{~d}^{-1}$ of Eurytemora affinis nauplii and $62 \% \mathrm{~d}^{-1}$ of chlorophyll in the northern reach of the estuary (Table 5). The calculated time to decline to $12 \%$ of the E. affinis population is $73 \mathrm{~d}$. This is somewhat shorter than the observed decline, which took several months; if nauplii are less than $100 \%$ vulnerable to predation the calculated time scale would be longer.

Our data show that the abundance of Eurytemora affinis and the other 2 species of copepod declined sharply at about the time of the spread of Potamocorbula amurensis. Our estimates of clearance rate are consistent with the explanation of the decline in copepods as due to predation by clams. There is no evidence of increased food limitation in the E. affinis population. Thus we have strong, if circumstantial, evidence that predation by clams caused the decline in the copepod population.

Potamocorbula amurensis has become well established in this estuary since the beginning of the recent drought (Carlton et al. 1990, Nichols et al. 1990). Although it would be premature to forecast a permanent change in the zooplankton, there is cause for concern: several species of fish that pass through their larval stages in the upper estuary are also in a serious state of decline (Stevens et al. 1985, Moyle et al. 1992)
The differences in predation rates on different species in the preliminary experiments are provocative. Differences in predation by fish or other predators on zooplankton prey are often described by terms such as 'selectivity' or 'preference'. The influence of prey escape mechanisms on predator 'choice' is often overlooked. It is unlikely that a clam could select one copepod nauplius over another.

Certain copepod species are numerically dominant in many estuaries and marine bays at least partly because of the low vulnerability of adults and copepodites to predation (Kimmerer 1991, Ueda 1991). Similarly, differences in vulnerability to predation by bivalves, if borne out by further experimental work, could have implications for the control of copepod species composition. Bivalves are highly abundant in many shallow estuaries and bays (Nichols 1985). Potamocorbula amurensis does not appear particularly unusual in size or strength of siphon currents, so one might expect a substantial grazing impact on zooplankton populations wherever high abundance of bivalves occurs in shallow water. This predation should be selective if there are differences in escape responses of the nauplii. Thus it is likely that benthic grazing could exert considerable control on the abundance and species composition of zooplankton in these locations.

Acknowledgements. Funding was provided to J.O. by the California Interagency Ecological Studies Program and Department of Fish and Game and to W.K. and E.G. by the California Department of Water Resources. We thank Doug Ball for helpful discussions, Zach Hymanson for data on abundance of clams, Randy Brown for encouragement and funding, Lee Mecum, Greg Schmidt, and Sally Skelton for help with fieldwork and sample analysis, Ai-Ling Chai for help with data analysis, Cathy O'Riordan and Jeff Koseff for helpful discussions, Barbara Sullivan for helpful reviews and encouragement, and Doug Ball, Bill Bennett, Pat Brandes, Ann Durbin, Zach Hymanson, Peggy Lehman, Bill Peterson, and Don Stevens for helpful comments on earlier drafts. 


\section{LITERATURE CITED}

Alpine, A. E., Cloern, J. E. (1992). Trophic interactions and direct physical effects control phytoplankton biomass and production in an estuary. Limnol. Oceanogr. 37. 946-955

Ambler, J. W. Cloern, J. E., Hutchinson, A. (1985). Seasonal cycles of zooplankton from San Francisco Bay. Hydrobiologia 129: 177-197

Arthur, J. A., Ball, M. D. (1979). Factors influencing the entrapment of suspended material in the San Francisco bay-delta estuary. In: Conomos, I J. (ed.) San Francisco Bay: the urbanized estuary. American Association for the Advancement of Science, San Francisco, p. 143-174

Berggreen, U., Hansen, B., Kiorboe, T (1988). Food size spectra, ingestion and growth of the copepod Acartia tonsa during development: implications for determination of copepod production. Mar. Biol. 99: 341-352

Bingham, B. L., Walters, L. J. (1989). Solitary ascidians as predators of invertebrate larvae-evidence from gut analyses and plankton samples. J. exp. mar. Biol. Ecol. 131: $147-159$

Buss, L. W., Jackson, J. B. C. (1981). Planktonic food availability and suspension-feeder abundance: evidence of in situ depletion. J. exp. mar. Biol. Ecol. 49: 151-161

Cariton, J. T., Thompson, J. K., Schemel, L. E., Nichols, F. H. (1990). Remarkable invasion of San Francisco Bay (California, USA) by the Asian clam Potamocorbula amurensis. 1. Introduction and dispersal. Mar. Ecol. Prog. Ser. 66: 81-94

Cloern, J. E. (1982). Does the benthos control phytoplankton biomass in south San Francisco Bay? Mar. Ecol. Prog. Ser 9: $191-202$

Cloern, J. E., Alpine, A., Cole, B., Wong, R., Arthur, J., Ball, M. (1983). River discharge controls phytoplankton dynamics in the northern San Francisco Bay estuary. Estuar. coast Shelf Sci. 16: 415-429

Cohen, R. R. H., Dresler, P. V., Phillips, E. J. P., Cory, R. L. (1984). The effect of the Asiatic clam, Corbicula fluminea, on phytoplankton of the Potomac River, Maryland Limnol. Oceanogr. 29: $170-180$

Cole, B. E., Thompson, J. K., Cloern, J. E. (1992). Measurement of filtration rates by infaunal bivalves in a recirculating flume. Mar. Biol. 113: 219-225

Cowden, C., Young, C. M., Chia, F. S. (1984). Differential predation on marine invertebrate larvae by two benthic predators. Mar. Ecol. Prog. Ser. 14: 145-149

Doering, P. H., Oviatt, C. A. (1986). Application of filtration rate models to field populations of bivalves: an assessment using experimental mesocosms. Mar. Ecol. Prog. Ser. 31. $265-275$

Eckman, J. E., Peterson, C. H., Cahalan, J. A. (1989). Effects of flow speed, turbulence, and orientation on growth of juvenile bay scallops Argopecten irradians concentricus (Say). J. exp. mar. Biol. Ecol. 132: 123-140

Edmondson, W. T (1968). A graphical method for evaluating the use of the egg ratio for measuring birth and death rates. Oecologia 1:1-37

Ertman, S. C., Jumars, P. A. (1988). Effects of bivalve siphonal currents on the settlement of inert particles and larvae. J. mar. Res. 46: 797-813

Fernandez, F. (1979). Nutrition studies in the nauplius larva of Calanus pacificus (Copepoda: Calanoida). Mar. Biol. 53 $131-147$

Ferrari, F. D., Dearborn, J. H. (1989). A second examination of predation on pelagic copepods by the brittle star Astrotoma agassizu. J. Plankton Res. 11: 1315-1320

Fréchette, M., Bourget, E. (1985a). Energy flow between the pelagic and benthic zones: factors controlling particulate organic matter available to an intertidal mussel bed. Can. J. Fish. Aquat. Sci. 42: 1158-1165

Fréchette, M., Bourget, E. (1985b). Food-limited growth of Mytilus edulis $\mathrm{L}$. in relation to the benthic boundary layer. Can. J. Fish. Aquat. Sci. 42: 1166-1170

Fréchette, M., Butman, C. A., Geyer, W. R. (1989). The importance of boundary-layer flows in supplying phytoplankton to the benthic suspension feeder, Mytilus edulis L. Limnol. Oceanogr. 34: 19-36

Heinle, D. R., Flemer, D. A. (1975). Carbon requirements of a population of the estuarine copepod Eurytemora affinis. Mar. Biol. 31: 235-247

Herbold, B., Jassby, A. D., Moyle, P. M. (1992). Status and trends report on aquatic resources in the San Francisco Estuary. San Francisco Estuary Project, U.S. Environmental Protection Agency, San Francisco

Horsted, S. J., Nielsen, T. G., Riemann, B., Pock-Steen, J., Bjornson, P. K. (1988). Regulation of zooplankton by suspension-feeding bivalves and fish in estuarine enclosures. Mar. Ecol. Prog. Ser. 48: 217-224

Hunt, J. H., Ambrose, W. G. Jr, Peterson, C. H. (1987). Effects of the gastropod, Ilyanassa obsoleta (Say), and the bivalve, Mercenaria mercenaria (L.), on larval settlement and juvenile recruitment of infauna. J. exp. mar. Biol. Ecol. 108: $229-240$

Hymanson, Z. P. (1991). Results of a spatially intensive survey of Potamocorbula amurensis in the upper San Francisco Bay estuary. California Interagency Ecological Studies Program Technical Report 30, Sacramento

Jumars, P. A., Nowell, A. R. M. (1984). Fluid and sediment dynamic effects on marine benthic community structure. Am. Zool. 24: 45-55

Kimmerer, W. J. (1987). The theory of secondary production calculations for continuously reproducing populations Limnol. Oceanogr. 32: 1-13

Kimmerer, W. J. (1991). Predatory influences on copepod distributions in coastal waters. In: Uye, S.-I., Nishida, S., Ho, J.-S. (eds.) Proceedings of the fourth international conference on Copepoda. Bull. Plankton Soc. Japan, Spec. Vol., p. 161-174

Landry, M. R. (1978). Population dynamics and production of a planktonic marine copepod, Acartia clausii, in a small temperate lagoon on San Juan Island, Washington. Int. Revue ges. Hydrobiol. 63: 77-119

Levinton, J. S. (1991). Variable feeding behavior in 3 species of Macoma (Bivalvia, Tellinacea) as a response to water flow and sediment transport. Mar. Biol. 110: 375-383

Loo, L. O., Rosenberg, R. (1989). Bivalve suspension-feeding dynamics and benthic pelagic coupling in an eutrophicated marine bay. J. exp. mar. Biol. Ecol. 130: 253-276

MacIsaac, H. J., Sprules, W. G., Leach, J. H. (1991). Ingestion of small-bodied zooplankton by zebra mussels (Dreissena polymorpha) - can cannibalism on larvae influence population dynamics? Can. J. Fish. Aquat. Sci. 48: 2051-2060

McLaren, I. A. (1965). Relationship between temperature and egg size, body size, development rate, and fecundity of the copepod Pseudocalanus. Limnol. Oceanogr. 10: 528-538

Monismith, S. G., Koseff, J. R., Thompson, J. K., O'Riordan, C. A., Nepf, H. M. (1990). A study of model bivalve siphonal currents. Limnol. Oceanogr. 35: 680-696

Morton., B. (1983). Feeding and digestion in Bivalvia. In: Sanuidin, A.. Wilbure, K. (eds.) The Mollusca, Vol. 5, Physiology, Part 2. Academic Press, New York, p. 65-147

Moyle, P. B., Herbold, B., Stevens, D. E., Miller, L. W. (1992). Life history and status of delta smelt in the SacramentoSan-Joaquin Estuary, California. Trans. Am. Fish. Soc. 121: $67-77$ 
Muschenheim, D. K., Newell, C. R. (1992). Utilization of seston flux over a mussel bed. Mar. Ecol. Prog. Ser. 85: 131-136

Nagaraj, M. (1992). Cambined effects of temperature and salinity on the development of the copepod Eurytemora affinis. Aquaculture 103: 65-71

Nichols, F. H. (1985). Increased benthic grazing: an alternative explanation for low phytoplankton biomass in northern San Francisco Bay during the 1976-1977 drought. Estuar. coast. Shelf Sci. 21: 379-388

Nichols, F. H., Cloern, J. E., Luoma, S., Peterson, D. H. (1986). The modification of an estuary. Science 231: 567-573

Nichols, F. H., Thompson, J. K., Schemel, L. E. (1990). Remarkable invasion of San Francisco Bay (California, USA) by the Asian clam Potamocorbula amurensis. 2. Displacement of a former community. Mar. Ecol. Prog. Ser. 66: 95-101

O'Riordan, C. A., Monismith, S. G., Koseff, J. R. (in press). The effect of bivalve excurrent jet dynamics on mass transfer in a benthic boundary layer. Limnol. Oceanogr.

Officer, C. B., Smayda, T. J., Mann, J. R. (1982). Benthic filter feeding: a natural eutrophication control. Mar. Ecol. Prog. Ser. 9: $203-310$

Orsi, J. J., Bowman, T E., Marreli, D. C., Hutchinson, A. (1983). Recent introduction of the planktonic calanoid copepod Sinocalanus doerrii (Centropagidae) from mainland China to the Sacramento-San Joaquin Estuary of California. J. Plankton Res. 5: 357-375

Orsi, J. J., Mecum, W. L. (1986). Zooplankton distribution and abundance in the Sacramento-San Joaquin Delta in relation to certain environmental factors. Estuaries 9: 326-339

Peterson, D. H., Conomos, T. J., Broenkow, W. J., Doherty, P. C. (1975). Location of the non-tidal current null zone in northern San Francisco Bay. Estuar. coast. mar. Sci. 3: $1-11$

Peterson, W. T., Tiselius, P., Kiørboe, T. (1991). Copepod egg production, moulting and growth rates, and secondary production, in the Skagerrak in August 1988. J. Plankton Res. 13: 131-154

Roddie, B., Leakey, R., Berry, A. (1984). Salinity-temperature tolerance and osmoregulation in Eurytemora affinis (Poppe) (Copepoda: Calanoida) in relation to its distribution in the zooplankton of the upper reaches of the Forth Estuary. J. exp. mar. Biol. Ecol. 79: 191-211

Runge, J. A. (1985). Relationship of egg production of Calanus pacificus to seasonal changes in phytoplankton availability in Puget Sound, Washington. Limnol. Oceanogr. 30: 382-396

Sebens, K. P., Koehl, M. A. R. (1984). Predation on zooplankton by the benthic anthozoans Alcyonium siderium (Alcyonacea) and Metridium senile (Actiniaria) in the New England subtidal. Mar. Biol. 81: 255-271

This article was presented by M. R. Landry (Senior Editorial Advisor), Honolulu, Hawaiu, USA
Sekiguchi, H., McLaren, I. A., Corkett, C. J (1980). Relationship between growth rate and egg production in the copepod Acartia clausi hudsonica. Mar. Biol. 58: 133-138

Singarajah, K. V. (1969). Escape reactions of zooplankton: the avoidance of a pursuing siphon tube. J. exp. mar. Biol. Ecol. 3: 171-178

Shumway, R. H. (1988). Applied statistical time series analysis. Prentice Hall, Englewood Cliffs, NJ

Stevens, D. E., Kohlhorst, D. W., Miller, L. W., Kelley, D. W. (1985). The decline of striped bass in the Sacramento-San Joaquin Estuary, California. Trans. Am. Fish. Soc. 114: $12-30$

Sullivan, B. K., Banzon, P. V. (1990). Food limitation and benthic regulation of populations of the copepod Acartia hudsonica Pinhey in nutrient-limited and nutrientenriched systems. Limnol. Oceanogr. 35: 1618-1631

Sullivan, B. K., Doering, P. H., Oviatt, C. A., Keller, A. A., Frithsen, J. B. (1991). Interactions with the benthos alter pelagic food web structure in coastal waters. Can. J. Fish. Aquat. Sci. 48: 2276-2284

Ueda, H. (1991). Horizontal distributions of planktonic copepods in inlet waters. In: Uye, S.-I., Nishida, S., Ho, J.-S. (eds.) Proceedings of the fourth international conference on Copepoda. Bull. Plankton Soc. Japan, Spec. Vol., p. $143-160$

UNESCO (1981). Tenth report of the Joint Panel on Oceanographic Tables and Standards. Sidney, BC

Vidal, J. (1980). Physioecology of zooplankton. I. Effects of phytoplankton concentration, temperature, and body size on the growth rates of Calanus pacificus and Pseudocalanus sp. Mar. Biol. 56: 111-134

Walker, D. R., Peterson, W T. (1991). Relationships between hydrography, phytoplankton production, biomass, cell size and species composition, and copepod production in the southern Benguela upwelling system in April 1988. S. Afr. J. mar. Sci. 11: 289-305

Werner, I., Hollibaugh, J. T (1993). Potamocorbula amurensis (Mollusca, Pelecyopoda): comparison of clearance rates and assimilation efficiencies for phytoplankton and bacterioplankton. Limnol. Oceanogr. 38: 949-964

Williams, J. G. (1980). The influence of adults on the settlement of spat of the clam, Tapes japonica. J. mar Res. 38 : $729-741$

Wright, R. T., Coffin, R. B., Ersing, C. P., Pearson, D. (1982). Field and laboratory measurements of bivalve filtration of natural bacterioplankton. Limnol. Oceanogr. 27: 91-98

Young, C. M. (1989). Larval depletion by ascidians has little effect on settlement of epifauna. Mar Biol. 102: 481-489

Young, C. M., Gotelli, N. (1988). Larval predation by barnacles: effects on patch colonization in a shallow subtidal community. Ecology 69: 624-634

Manuscript first received: November 30, 1993

Revised version accepted: May 16, 1994 